This is a self-archived version of an original article. This version may differ from the original in pagination and typographic details.

Author(s): Kamran, Sohail; Uusitalo, Outi

Title: Banks' unfairness and the vulnerability of low-income unbanked consumers

Year: 2019

Version: Accepted version (Final draft)

Copyright: (c) 2018 Informa UK Limited, trading as Taylor \& Francis Group.

Rights: In Copyright

Rights url: http://rightsstatements.org/page//nC/1.0/?language=en

Please cite the original version:

Kamran, S., \& Uusitalo, O. (2019). Banks' unfairness and the vulnerability of low-income unbanked consumers. Service Industries Journal, 39(1), 65-85.

https://doi.org/10.1080/02642069.2018.1436704 


\title{
Banks' Unfairness and the Vulnerability of Low-income Unbanked Consumers 银行的不公平与低收入无银行账户消费者的脆弱性
}

\begin{abstract}
This paper's objective was to explore low-income unbanked consumers' perceptions of bank fairness and the way these perceptions were linked to consumer experiences of vulnerability. Qualitative data were used to analyse low-income consumers' perceptions about banks' services and communications. The study finds that although consumers' financial inclusion is partially hindered by their personal circumstances, the perceived unfair treatment by banks has an even more negative impact on their financial inclusion. Low-income unbanked individuals report banks avoiding them, discriminating against them and impeding their financial inclusion. Banks' perceived unfairness towards low-income consumers leads those consumers to experience vulnerability in numerous ways. Finally, we provide public policy implications for low-income consumers' well-being and financial inclusion and to assist them in mitigating their vulnerability.
\end{abstract}

摘要

本文的目标是探讨低收入无银行账户的消费者对银行公平的看法, 以及这些看法与消 费者脆弱性体验相爸联的方式。定性数据被用来分析低收入消费者对银行服务和沟通 的看法。研究发现, 尽管消费者的金融包容性在一定程度上受到其个人处境的部分阻 碍，但银行的不公平待遇对其金融包容性的负面影响更大。低收入无银行账户的个人 反映银行避开他们, 歧视他们, 
妨碍其普惠金融。银行对低收入消费者的不公平导致这些消费者在许多方面感受到了

脆弱性。最后, 我们提供了对低收入消费者的福利和金融包容的公众政策启示并帮助

他们减轻其脆弱性。

Key words: Vulnerability, fairness, unbanked, exclusion, developing country

䏌键词：脆弱性，公平性，无银行账户，排除，发展中国家

\section{Introduction}

Approximately five billion people in the world live in different levels of poverty (Fisk et al., 2016), and they often lack access to essential services (Anderson et al., 2013). For example, low-income consumers lack access to conventional financial services (e.g., Koku, 2009) and utilize alternative offerings to manage their routine financial matters (Laureti, 2017). In the context of developing countries, the vast majority of the population remains unbanked (Demirguc-Kunt, Klapper, Singer, \& vanOudheusden, 2015), and most of those unbanked people live on a low-income (see Kochhar, 2015). Banks avoid serving low-income groups because they are considered unprofitable (Chéron, Boidin, \& Daghfous, 1999). The deficiencies in service systems often adversely affect the well-being of low-income consumers (Fisk et al., 2016). For example, financial service providers can adversely affect poor consumers' well-being through poor service design, processes and the lack of access to a service (Anderson et al., 2013). The exclusion of the poor from mainstream financial services is unfair and socially unacceptable (Chéron et al., 1999), and it leads them to experience vulnerability (Cartwright, 2011). Ensuring fair dealings for low-income unbanked consumers requires a deep understanding of their position as customers. Banks' policies and 
procedures discourage financial inclusion of the poor (Koku, 2009; Solo, 2009). Vulnerable, financially excluded consumers are dependent on marketers to create fairness for them in the marketplace (Baker, Gentry \& Rittenburg, 2005). However, few studies have considered the unbanked consumers' perspective, there is a dearth of research on financial exclusion in the field of marketing (Koku, 2015) and customers' perception of banks' fairness towards them (Worthington \& Devlin, 2013).

Service firms (e.g. banks) have been blamed for damaging human well-being in various ways such as, by poorly treating and ignoring customers who need a particular service (Fisk, 2009). Transformative Service Research (TSR) movement addresses this issue and aims to advance fair services for the welfare of human beings (Anderson et al., 2013). TSR places specific emphasis to investigating problems of developing countries low-income consumers who are marginalized and excluded from various service domains (Gebauer \& Reynoso, 2013; Fisk et al., 2016; Reynoso, Valdés, \& Cabrera, 2015). Service research conducted among affluent customer groups is not pertinent to poor consumers (Reynoso et al., 2015; Gebauer \& Reynoso, 2013). TSR highlights the importance of research in the realm of financial services for the well-being of poor (Anderson et al., 2013). Over two billion world's poor population is unbanked (Chopra, Prabhala \& Tantri, 2017) and their financial exclusion imposes considerable costs on them (Solo, 2008). Hitherto, a little research is conducted on lowincome consumers of financial services within TSR stream but service scholars' unique understanding about service processes can lead to research contributions and endeavours to uplift their well-being (Anderson et al., 2013). Sanchez-Barrios, Giraldo, Khalik, \& Manjarres (2015) explored effects of loan sharks on the well-being of poor consumers, and found that loan sharks offer unbiased, hassle-free, without using technical jargons and reputation based lending to poor consumers. The study concluded that these positively 
influence poor consumers' well-being. The study suggests that formal service providers can serve the poor in better ways by implementing positive practices of informal lenders. Martin \& Hill (2015) utilized a worldwide sample to investigate the ways in which social poverty, personal saving capability and satisfaction with individual's household financial circumstances effect the welfare of poor consumers. They found that an increase in societal poverty considerably decrease well-being. However, in impoverished nations savings significantly enhance well-being. Thus, research that promotes an impartial delivery of basic banking services to low-income unbanked consumers can uplift their well-being.

Banks unfairness towards low-income consumers hamper fulfillment of their consumption goals (Kempson \& Whyley,1999) and in such situations they are prone to encounter vulnerability (Baker et al., 2005). However, to the best of our knowledge, prior researchers have not explicitly addressed the role of service providers unfairness in making their customers experience vulnerability. The present research explores how low-income unbanked consumers perceive the fairness of bank policies and service processes and how these perceptions are connected to their experience of vulnerability. This research contributes to TSR by providing understanding of seldom addressed concerns of low-income unbanked consumers regarding the consequences of their negative marketplace encounters (Anderson et al., 2013). The study offers viable implications for their financial inclusion and fair treatment which could help to mitigate their marketplace vulnerability and enhance their well-being. Besides TSR literature, this study contributes to consumer vulnerability research in three ways. First, it links service providers' justice elements to consumers' experience of vulnerability. In particular, it elucidates how service providers' unfairness prevent consumers' consumption goals thus causing them vulnerability. Second, it highlights the role of uncontrollable external factors in low-income consumers' marketplace exclusion and 
vulnerability. Third, it uncovers low-income consumers perceptions regarding service provider fairness and the way those perceptions contribute to their experience of vulnerability.

\section{Theoretical background}

\subsection{Justice Theory}

Apart from other business fields, justice theory has been vastly utilized in studying service firms' fairness towards their customers (Seiders \& Berry, 1998). Service firms' injustice towards customers can cause customers stress in their ordinary lives (Wang \& Tian, 2014) and can trigger perceptions of unfairness among customers (Seiders \& Berry, 1998). For instance, service firms typically exclude less-profitable customers and thus hinder their wellbeing (Speak, 2000). This practice is apparent in the financial services sector where the poor face negative attitudes from financial services providers (e.g., Kempson \& Whyley, 1999), which often results the financial exclusion of those consumers. For example, banks' discrimination against less affluent consumers prevents their financial inclusion (e.g. Wang \& Tian, 2014). Three justice components, distributive, procedural and interactional, are generally used to evaluate the service fairness of a firm (Seiders \& Berry, 1998).

Distributive justice refers to the fair allocation of benefits and costs (Laczniak, 1999) and is considered a social performance measure in marketing and other social settings (Klein, 2008). 'Distributive justice is concerned with the distribution of conditions and goods which affect individual well-being (Deutsch, 1975, p. 137). Three distribution principles, equity, equality, and need, are commonly acknowledged (Deutsch, 1975; Seiders \& Berry, 1998). Relations 
between parties establish particular distribution patterns. Equity is generally a dominating rule for achieving better economic productivity (Deutsch, 1975). This implies that more resources should be allocated to profitable and loyal customers due to their greater input into the business. Equality will be a chief principle for preserving enjoyable social relations. Thus, resources are distributed equally to all customers regardless of their business worth. Customers usually expect and prefer equality during their economic exchanges. Finally, need is the foremost principle when the goal is personal welfare. If a business pursues this principle, then resource allocations will be proportional to the needs of particular customers (Deutsch, 1975; Seiders \& Berry,1998).

Procedural justice addresses customers' perception of fairness in any of a firm's procedures (Tax, Brown, Chandrashekaran, 1988; Chung-Herrera, 2007). Procedural justice refers to the level of equity, impartiality, and freedom from bias inherent in the specific manners of achieving social exchange outcomes. Procedural justice concerns the ways in which an outcome is achieved (Nance \& White, 2009). Numerous procedural justice violations are possible, and customers in similar situations may be treated differently by the firm. For instance, two comparable customers experience different procedures during their complaint resolutions; one talks to the manager about the issue, whereas another fills out a lengthy complaint form (Chung-Herrera, 2007). Previous studies have identified six procedural fairness principles:(i) consistent processes across people and time, (ii) unbiased processes, (iii) accuracy of information, (iv) correctability of errors and flawed decisions, (v) obeying of ethical standards, and (vi) ensuring that the viewpoints of different groups affected by a decision are considered (Leventhal, Karuza, \& Fry, 1980; Colquitt, Conlon, Wesson, Porter, $\& \mathrm{Ng}, 2001)$ 
Interactional justice refers to characteristics of interpersonal behaviour rather than formal principles (Seiders \& Berry, 1998). It addresses the type of treatment customers receive from service firm employees (Blodgett, Hill \& Tax, 1997; Tax et al., 1998). Interactional justice is further divided into informational and interpersonal justice. Informational justice is the appropriateness of information or explanations that are provided in timely, precise and truthful manner, whereas interpersonal justice refers to the ways in which individuals are treated by the organization or its staff. Customers' assessment of interactional justice is dependent on the way they are treated by the service firm (Tax et al., 1998). Some attributes of interactional justice include honesty, respect (Seiders \& Berry,1998), neutrality (Namkung \& Jang, 2009) trust, communication (Blodgett et al., 1997), politeness, expressing concern, professional decorum, courtesy and candour (Seiders \& Berry,1998).

While the financial exclusion of underprivileged consumers has not been approached from the fairness perspective by pervious researchers, extant literature signals that low-income consumers may be treated unfairly by banks. They could experience distributive injustice, e.g., geographical barriers to banking (Kempson \& Whyley, 1999); procedural injustice, e.g., banks establish procedures that are difficult for them to fulfil (e.g., Solo, 2008); and interactional injustice, e.g., negative attitudes from bank staff towards the poor (Chéronet al., 1999). Their financial inclusion is denied or hindered due to the injustice of banks, and those experiences may adversely affect their personal and social perceptions of self (Baker et al., 2005). However, it is somewhat unclear how experiences of unfairness lead low-income consumers to experience vulnerability.

\subsection{Consumer vulnerability and bank services}


Types of consumers, such as the poor and illiterate, are considered vulnerable and warrant extra support in the marketplace (Brennan, 2006). Definitions of 'vulnerable consumers' generally include either a targeted product, an economic transaction that has occurred, or a consumption context that has been experienced by consumers (see Smith \& Cooper-Martin, 1997; Ringold, 1995; Morgan, Schuler, \& Stoltman, 1995), and due to personal vulnerable circumstances, individuals fail to maximize their utility and well-being in these types of economic transactions (Smith \& Cooper-Martin, 1997). There are instances in which service providers avoid exchanges with some customers (Mayser \& von Wangenheim, 2013). Consumer vulnerability refers to a situation in which consumers encounter powerlessness and a lack of control due to service provider bias against serving them. Vulnerable consumers depend on external parties to introduce fairness into the marketplace. The actual vulnerability occurs as a result of the interaction of personal and external circumstances in situations where consumption objectives are hampered and the experiences adversely affect both the individual and the social perception of self (Baker et al., 2005).

While consumers could encounter vulnerability in marketplace transactions owing to their personal circumstances (Gentry, Kennedy, Paul \& Hill, 1995),e.g., poverty and illiteracy (Brennan, 2006), these individual characteristics are not the sole basis on which to delineate consumer vulnerability (Baker et al., 2005). Another form of vulnerability is caused by the environment in which people live (Wang \& Tian, 2014; Baker et al., 2005). People are at a risk of experiencing powerlessness due to uncontrollable external factors, e.g., natural disaster (e.g., Baker, Hunt, \& Rittenburg, 2007) and marketplace discrimination. Consumers experience powerlessness when their environment creates barriers to their participating in society (Wang \& Tian, 2014; Baker et al., 2005). Different uncontrollable external factors could trigger an experience of vulnerability, including allocation of resources; physical and 
logistical aspects; stigmatization and repression; and other conditions, such as social, economic and political upheaval. These factors add to the imbalance of power in exchange relationships that disfavour consumers (Baker et al., 2005, p.130). Consumers could encounter powerlessness when they have a lack of choice and control because of disproportionally greater power between the seller and the customers (Rayburn, 2015). In the case of financial services, consumers typically experience vulnerability in understanding information about financial products because it is often presented in a technical and complex manner (Cartwright, 2011). Nevertheless, low-income consumers, who generally possess low literacy skills (Cartwright, 2011; Laureti, 2017), are more prone to encounter powerlessness in understanding financial product information (Cartwright, 2011). Thus, both internal and external factors can activate consumer experiences of marketplace powerlessness (Baker et al., 2005).

Anyone can undergo a state of powerlessness in the marketplace, but it is usually a temporary affair (Baker et al., 2005). Consumers' powerlessness often causes them harm, such as physical, financial or psychological losses (Smith \& Cooper-Martin, 1997). Mainstream consumers possess adequate resources that help them to effectively address their marketplace powerlessness and allow them to obtain control of their lives. However, the marketplace powerlessness experienced by low-income consumers is generally prolonged due to their feeble economic circumstances and marketplace conditions that are unreceptive towards them (Baker et al., 2005; Saatcioglu \& Corus, 2016). The poor can be excluded, marginalized and discriminated against by service providers owing to their limited resources and capacities (Fisk et al., 2016). Their lack of material resources is a commonly considered a cause of their exclusion from different consumption spheres (Saatcioglu \& Corus, 2016). 
A lack of personal control is a basic aspect of the consumer experience of vulnerability. Economically susceptible consumers typically lack control in different consumption spheres, which causes them marketplace vulnerability (Hill \& Stephens, 1997; Baker et al., 2005). Previous studies have described various events during which low-income consumers experience vulnerability in the context of financial services. These experiences usually reflect powerlessness due to a lack of control over consumers' personal circumstances such as poverty (e.g., Solo, 2008; Kempson \& Whyley, 1999). Moreover, these consumers lack control over external conditions, such as banks' negative behaviour towards the poor (e.g., Chéronet al., 1999). The practices of conventional lenders are beyond the control of many consumers and prevent them from accessing credit from formal sources (Canhoto \& Dibb, 2016). The discriminatory policies of banks oblige financially excluded consumers to obtain control of their financial lives through informal sources, which often results in marketplace vulnerability (Wang \& Tian, 2014).

Experiences of vulnerability are closely related to the perception of one's ability to address a consumption situation, and it may shape both present and future perceptions of self (Baker et al., 2005). Vulnerable consumers desire to be treated with equality and respect by the seller (Baker, 2006). They form opinions regarding the way they are treated by others. Positive judgements enhance self-perceptions, and negative opinions diminish the self (Baker et al., 2005). It is the responsibility of service firms to treat vulnerable customers with respect and provide them fair treatment (Rendtorff, 2009) because they need to be protected in the marketplace; sometimes, they are exploited by marketers (Kennedy \& Laczniak, 2016).

In summary, banks' policies, procedures and unwelcoming staff behaviour can prevent lowincome consumers' from accessing basic banking services. Rather than consumers' internal 
factors, it is the banks' justice elements, as uncontrollable external factors, that discourage financial inclusion. Low-income consumers' perceptions regarding the banks' justice elements may be connected to their experience of vulnerability.

\subsection{TSR and the unbanked consumers}

Different service entities such as service employees, processes, offerings, organizations and service sectors have the potential and power to positively or adversely affect consumers' well-being (Anderson et al., 2013; Fisk et al., 2016). Both consumer vulnerability and justice related studies have a public policy element, as imbalance created by unfair marketing practices can be corrected through regulations or policy interventions (Gundlach \& Murphy, 1993). TSR emphasizes the mechanisms by which service firms can facilitate well-being through positive changes and improvements (Pera \& Viglia, 2015; Corus \& Saatcioglu, 2015). Reinforcing TSR suggests that service providers ought to be held responsible for their influence on different groups within a society, such as the poor, who are worthy of being served appropriately by those service firms (Fisk et al., 2016). Supply side interventions could help people lacking access to basic bank accounts to join the formal financial system (Chopra et al., 2017). TSR focuses on mitigating consumer vulnerability and increasing consumer agency (Corus \& Saatcioglu, 2015). Because the vulnerability of financially excluded consumers primarily stems from banks' hostile attitudes towards them, consumer advocacy and better policy making can reduce this vulnerability (Wang \& Tian, 2014).

Studies related to the transformative sphere in financial services can uplift marketplace fairness for vulnerable consumers (Anderson et al., 2013), which could assist them to escape vulnerability (Wang \& Tian, 2014). This research follows the TSR course, which seeks to 
understand the issues faced by low-income unbanked consumers. It attempts to foster change for the fair treatment of low-income consumers and to discover better ways to serve them to enhance their well-being (Fisk et al., 2016). TSR connects to transformative consumer research (Mick, 2006) and service research to benefit consumers' well-being. It advocates quality of life issues that are vital for the well-being of consumers. TSR agenda highlights significance of research related to financial services' impact on poor individuals because access to basic financial services is considered an important ingredient for the well-being of modern-day people (Anderson et al., 2013). Therefore, the present study seeks a deeper understanding of how different aspects of banks' justice contribute to low-income consumers' experiences of vulnerability in a developing country context.

\section{Methodology}

\subsection{Sample and data collection}

The empirical study was conducted in Pakistan, where $79.5 \%$ of the population were living on a low-income in 2011, their income being less than or equal to USD10 per day/USD3650 per year (Kochhar, 2015). Further, 87\% of Pakistani adults were unbanked (Demirguc-Kunt et al., 2015). We attempted to gain a deep understanding of the experiences and views of lowincome unbanked consumers regarding banks' services and processes. Semi-structured interviews were employed in the data collection. We completed 37 interviews in four lowincome areas of Rawalpindi and Islamabad; 28 interviews were completed in 2014 and 9 in 2015. These four areas were selected because they were accessible to the researcher. The participants were selected through a purposeful sampling technique based on their own experience of being financially excluded, which implied that they were unbanked. Social ties 
were helpful in recruiting interviewees from low-income neighbourhoods because people tend to be reluctant to freely talk to an interviewer whom they do not know. Therefore, initially one low-income unbanked consumer with strong social connections in their respective communities were recruited from each of the four neighbourhoods. They were asked to facilitate the recruitment of more participants who could talk about their experiences of being unbanked in detail. This strategy proved to be helpful in gathering data. The informant group comprised 13 females and 24 males who volunteered to participate in the study and had been working at various low-income earning professions. The monthly income of the informants ranged from Pak Rupees 7000-26000/USD67-249; therefore, they are categorized as low-income (see Kochhar, 2015). Migrant workers (MW) who relocated from villages to the city for work purposes accounted for 25 participants, and 12 informants were local residents of Islamabad or Rawalpindi, Pakistan. Table 1 presents the profiles of the participants.

\section{Insert table1 here.}

The interviews were completed in different places based on the convenience to and preferences of the informants. These places included the participants' houses, shops and neighbourhood restaurants. The informants were given small financial incentives in the local currency equalling USD 3. The university's ethical guiding principles were followed while working with the low-income unbanked informants. Because the majority of the informants were either illiterate or less literate, the information sheet and consent forms were also explained to them verbally prior to the start of the interviews in order to ensure their understanding of the study's purpose. We also assured the informants of confidentiality and anonymity. We developed interview guidelines that were composed of questions related to 
the informants' demographic profiles, personal and external factors that hamper their financial inclusion, their experiences with the bank staff during their visits to bank branches, their perception of the banks' fairness towards them and the consequences of banks unfairness in terms of vulnerability.

The wording and order of the interview questions were kept fairly flexible to accommodate the situation and the study participants' characteristics during the interviews. The interview questions were asked in a non-directive manner to motivate informants to express their views in detail during the interviews (Elliott \& Jankel-Elliott, 2003). Thirty-four interviews were performed in Urdu and three were conducted in Punjabi; all the interviews were completed by the first author who possesses fluency in both languages. The interviews were audio-recorded with the consent of the informants. The interviews were conducted until the last few interviewees did not provide considerably new information compared to the previous interviewees. This was considered to be a sign of saturation (Myers, 2013), and thus the final sample size was reached. The duration of interviews ranged from twenty-two minutes to slightly more than an hour. This resulted in almost 20 hours of records that were transcribed verbatim. While reporting the data in this study, pseudonyms were applied to protect the identities of the participants.

\subsection{Data analysis}

We utilized a thematic analysis technique to identify, analyse and report themes inside the dataset. This method of data analysis not only allowed us to organize and explain the dataset in a rich detail but also permitted us to interpret different aspects of the study topic (Braun \& Clarke, 2006). The accuracy of the interview transcripts was verified again by listening to the audio-recorded interviews on several occasions (Bird, 2005). The understandability of the 
data was enhanced by reading it several times, which was followed by the identification of preliminary codes in the entire dataset. Given the exploratory nature of this study, a bottomup-approach, in which data-driven coding was applied to the entire dataset, was utilized (Myers, 2013).The codes were also written on a separate sheet to facilitate comprehension and analysis. An analysis at a broader level was subsequently conducted to ascertain the likelihood of combining codes with themes. This plan facilitated our classification of a list of preliminary subthemes and themes. The themes were then reviewed and refined, which helped to ensure that the themes had sufficient support from the data. Initially, themes were evaluated at the coded data extract level and subsequently at the complete dataset level. With reference to a particular theme, the data were revisited several times when necessary to determine the missing information and increase the support for themes within the transcribed data. To ensure that themes fit with the codes, notes about each theme were taken on separate piece of paper for an in-depth understanding and accurate reporting of the themes. We then explained the meanings of the themes and identified which elements of the data are linked to each theme. In so doing, the data were first analysed independently, and initial themes were identified. However, the literature provided in this paper also aided us in refining and finalizing subthemes and themes, as we intended to name the subthemes and themes in a way that explicates their relevance to the study question. Finally, an analysis of each theme was presented, and quotes from the data were provided to support the arguments (Braun \& Clarke, 2006).

\section{Findings}

The data indicate that banks' processes for serving low-income customers contain issues that can be scrutinized from the fairness perspective. Low-income unbanked participants' 
perceptions regarding a bank's fairness towards them is elucidated in three themes: resource allocation, bank procedures and service encounters with frontline bank employees. The concepts of distributive, procedural and interactional justice can be applied to describe the experiences of the participants. The participants' stories indicate that they encountered unfair treatment in banks when they visited to open an account, pay utility bills, or both. The participants' descriptions highlight instances in which they were avoided and discriminated against by banks, impeding their financial inclusion.

The participants' experiences in situations in which they encountered unfair treatment and felt vulnerability at the banks can be analysed through three themes: avoiding, discriminating and impeding. First, avoidance is linked to the distributive and interactional justice elements of banks. Geographical barriers to banking and lack of knowledge about banks are distributive justice elements, and bank staff avoiding poor customers by providing them poor service is an interactional justice component. Second, participants perceived that banks discriminate against them. They expressed receiving discriminatory procedural treatment and disrespectful service from bank staff; these issues are related to the procedural and interactional justice elements of banks, respectively. Finally, the document and initial deposit requirement for a bank account are procedural justice elements. Banks' unfairness is an uncontrollable factor that leads to powerlessness and thus plays a central role in impeding low-income consumers' control over fulfilling their consumption goals (e.g., financial inclusion). 


\subsection{Avoiding low-income consumers}

The data indicate that banks' avoidance of low-income consumers resulted in geographical barriers to banking and a lack of knowledge about banks. Participants also felt avoided when they received poor service from the bank staff. Low-income participants face geographical barriers to banking and a lack of information regarding banks; these limitations have been linked to distributive justice elements of banks. Poor service is associated with the banks' interactional justice aspects. The banks avoidance caused the participants to experience vulnerability. Financial detriment resulted from the high transportation costs needed to reach a distant bank branch, which would decrease daily income; non-financial detriment was caused by the cost in time to reach a distant bank branch, the physical drain and the reprimand from employers due to time wasted visiting banks.

Geographical barriers appeared mostly with respect to the accounts of migrant workers who lived in villages but moved to the city for work purposes. Most of the Pakistani population lives in rural areas and are thus susceptible to financial exclusion because they cannot easily reach their bank branches. Low-income participants' personal characteristics (i.e., poverty) often prevented them from maintaining personal transportation or access to affordable transportation. A distant bank branch entails transportation and time costs. Thus, both their personal characteristics and external factors (i.e., geographical barriers) render them vulnerable. Poor customers usually incur greater costs in reaching a bank due to their residency in rural or disadvantaged areas compared to the mainstream urban consumers. They perceive a lack of control over their money if they open a bank account and keep money in banks because a distant bank branch prevents them from utilizing their money if it is urgently needed. Therefore, geographical barriers to banking also stimulated the participants' 
perception that there is little need or benefit in opening a bank account. Niaz encountered this barrier when he was living in a village; he explains his story in the following way:

There is no bank in village. We have to go far-off. That is why we have not opened a bank account...It is about 25-30 kilometres... I thought that if I opened a bank account and I needed money, then it would a problem. It is difficult to go to the bank because I often do not have time (Niaz, 26).

Some female participants who were local residents faced barriers to accessing bank branches due to the distance of a bank branch from their home and due to cultural conventions. Female participants depended on the company of male family members to reach to a bank branch. Izza, a housewife, narrates her story in the following paragraph:

The bank is also a little faraway; I cannot go alone, and I cannot send my husband there [Bank] either... If it [the bank] is very close then one can go... We understand it is a problem because it is difficult to go there. His [the husband's] health is not very good, and I cannot go alone...I really want to open a bank account, but then, I think that if I deposit money today, then I will have to go withdraw it tomorrow. Then, I have to take a taxi (Izza, 55).

The participants generally lack knowledge concerning banks. The illiterate participants in particular have no or very little knowledge of banks. These participants believe that at banks, they can only deposit money into their savings and then withdraw. Therefore, some participants never tried to open a bank account. While restricted income coupled with illiteracy may encourage financial exclusion among low-income participants, their lack of awareness concerning the advantages of opening bank accounts encouraged them to remain 
unbanked. They believed that one should only open a bank account when in the possession of significant money. The accounts of participants also imply that banks do not fairly allocate their promotional campaigns and consumer education budgets; thus, they feel neglected in marketing campaigns. The following quotation from an interview highlights that low-income unbanked consumers' lack information regarding banks and their functions.

Bank account? If I tell you the truth, I do not know what the advantages of banks are. What are the disadvantages? We have never been there. We do not know, so what we can say to you (Bari, 34)?

The participants believe that the bank staff avoids serving them by providing them with poor service. Low-income consumers' explanations regarding their interactions with the bank staff reflect interpersonal and informational justice issues. Lack of literacy skills exacerbate participants' experiences with bank staff, as the participants were sometimes unable to understand the bank staff's explanations. Further, participants' negative experiences regarding the bank's staff were exacerbated when the participants believed that they were receiving poor service in the form of a lack of cooperation, assistance and time management. Lack of assistance and inadequate information provided by the bank staff made low-income participants believe that they were being intentionally avoided by the bank staff. It was obvious from the participants' accounts that they expected extra assistance in their attempts to open an account, as they openly admitted the vulnerability that resulted from their poverty and illiteracy. However, perceptions of poor service discouraged participants from pursuing financial inclusion. A violation of interpersonal and informational justice and ensuing financial exclusion is evident in the following interview quote: 
Once I went to a bank, but I did not understand everything they told me. I could not understand, and then I did not go back...They [the staff] were talking with me quickly, and I could not understand this rush...they did not give me the right information explaining that this will happen like this, and this will happen like this. They were not listening. They said to bring this completed form. I told myself to leave this for now...I was hurt, and that is why I did not try again to open a bank account (Niaz, 26).

The participants' stories indicate that the poor service provided by the bank staff left the participants feeling reprimanded. The participants felt that their time had been wasted. For example, the staff told them to sit and wait, offering the excuse of a computer problem and telling them to come to the bank some other day. The bank staff were also told providing participants with inadequate information or gave them the wrong account opening options. The wasting of time often caused a decrease in the daily income of the study's participants, as they worked in informal professions. Participants also suffered from tiredness and were sometimes reprimand by their informal employers. The following interview passage explains how the bank staff wasted the time of one of their potential customers:

They do not listen to what we are saying; they first tell you to sit there... They made me go to the bank twice or thrice, and finally, I did not go to the bank (Papu, 26).

Based on the data analysis we conclude the following propositions concerning avoidance leads to consumers' perceptions of unfairness and experience of vulnerability:

P1: The banks distributive justice elements including geographical barriers to banking and lack of knowledge about banks prevent low-income consumers to engage successfully with banks and thus contribute to their experience of vulnerability. 


\section{P2: The poor service delivered to low-income consumers by banks staff discourage their}

financial inclusion and thus contribute to their experience of vulnerability.

\subsection{Discrimination against the low-income consumers}

Low-income participants reported discriminatory procedural treatment and disrespectful behaviour from bank service staff. The discriminatory procedural treatment indicates a procedural justice component, whereas disrespectful behaviour on the part of the banks is associated with an interactional justice element. The low-income participants experienced vulnerability due to perceived discrimination in ways that included feelings of powerlessness, seeing themselves as inferior to others and feeling insulted.

The data include service incidents that indicate discriminatory procedural treatment. Participants reported that social contacts, wealthy customers, well-dressed and educated people received better and expedited procedural treatment from the banks beyond that of the low-income consumers. The bank staff usually followed procedures that were lengthy and sometimes difficult for participants to follow (i.e. during utility bill payments and in their attempts to open an account). The participants believed that there should be similar procedures for everyone regardless of their economic situation or social connections with the bank staff. Nori explains her experience of procedural unfairness in the following way:

When we go to the bank, we see that when their [bank staff] acquaintance comes [to the bank], we keep standing there [in the queue], and he deposits the bill and goes (Nori, 40)

The participants differed in their orientation towards the unfair procedural treatment. A few participants believed that their loss of control while visiting the banks was solely due to 
external factors (i.e. discriminatory procedural treatment of banks). However, some participants blame both their personal (e.g. poverty and illiteracy) and external (e.g. banks discrimination) circumstances for restricting their control while trying to acquire or consume basic financial services. Nevertheless, when participants experienced discriminatory procedural treatment from a member of the bank staff, they experienced vulnerability as a result. Their stories specify that due to their lack of control, they perceived themselves as powerless and observed themselves as being inferior to those who were given better treatment by the bank staff. Such experiences of vulnerability are evident in the following interview excerpt:

We also feel shy when we go to the bank. They do not give us that reception that they give to more educated and well-dressed people... When I went to the bank, [bank] security personnel inspected me as though I were a suspect. Obviously, I went there in an ordinary Shalwar Kameez [Dress in Pakistan], and my clothes were not of very high quality. When I went there, the security staff member asked me why I came there and for what purpose (Phol, 46).

The participants' stories reveal that economically well-off customers are treated in a respectful manner by the bank staff, while the participants were addressed in a disrespectful way. This is an issue of interactional justice. The perceived negative behaviours of the bank staff forced the low-income unbanked participants to perceive themselves as less than others in the society. One disabled participant felt that he was handled in a disrespectful manner by bank staff due to his poverty:

They behaved with me in a way that indicated that I was their enemy. They did not talk to me in right manner. Who likes to talk with poor people? They did not talk with me properly. They did not think that they needed to listen to me since I came here on a wheel chair... with other 
customers they were behaving in a way as those are their brothers and sisters. No one listens to poor people (Noor, 32).

Some participants who were addressed in a disrespectful manner by a bank staff member felt insulted as a result of their service encounters. These patterns included bank staff asking participants about the origin of their money, telling them to go to another bank or branch, not listening to them carefully and behaving rudely. The problems in banks' interactional justice elements hampered financial inclusion of the participants and caused them to experience vulnerability. Pola gives his opinion in the following way:

Those who are from a lower class, those who obviously have 15 or 18 or 12 thousand [Pak Rupees] income -this is nothing for them [for banks], which means they do not deal well with us... One comes back [from bank] annoyed that it is better not to open a bank account because everyone likes to keep his respect (Pola, 29)

The following proposition summarizes how discrimination of low-income consumers relates to perceptions of unfairness and vulnerability:

P3: Procedural and interactional justice elements of banks' service are connected to discriminatory treatment of low-income consumers and contribute to their experience of vulnerability. 


\subsection{Impeding the financial inclusion of low-income consumers}

Procedural justice elements were visible in the data in shape of requirements of documents and initial deposits when opening a bank account. The data show how violating this justice component can impede financial inclusion and result in experiences of vulnerability. The requirement of certain documents to open a bank account impeded the financial inclusion endeavours of the participants. Many participants were working in informal professions in which money transactions are commonly completed in cash and employment contracts are rarely provided to employees. The participants considered these documentary obligations for opening a bank account to be unfair. This resulted in feelings of powerlessness and lack of control. The participants felt helpless because they thought their personal circumstances induced banks to exclude them from acquiring and consuming basic financial services. The following interview passage exemplifies the situation:

I told them that I do water bore work. I provided them full information, but in the end, he crossed the form that I completed and kept it with him. He said that my account could not be opened... if I did not have a business address and did not have any source of income... my bank account could not be opened...This [system] does not the favour a poor man. (Jani, 43).

The participants also expressed their inability to fulfil the initial deposit requirement for opening a bank account and they perceived this requirement to be unfair, as banks were treating the poor just as they would treat mainstream consumers in the account-opening processes. This condition hampered participants' control over accomplishing their consumption goal and triggered an experience of vulnerability. The following interview quotation explains this barrier: 
Once, I went to the bank, and they said, I think, to deposit ten thousand then my account would be opened. I did not think of opening a bank account after that... because there was no urgent need. If I had an urgent need, then I might have deposited ten thousand (Mani,27).

Low-income participants' personal characteristics (e.g., poverty and illiteracy) obstructed their financial inclusion to some extent. However, financial exclusion of the poor can primarily be blamed on banks' lack of fairness towards them. The low-income participants' accounts of their experiences in banks revealed service processes that implied distributive, procedural and interactional unfairness from banks (see table 2). The lack of bank fairness created a barrier to the fulfilment of the consumption goals of low-income consumers, which caused them to experience vulnerability in form of encountering different financial and nonfinancial types of harm.

The following proposition concludes how banks' policies impeding financial inclusion connects to perception of unfairness and vulnerability:

\section{P4: Banks procedural justice elements impede financial inclusion of low-income consumers and thus contribute to their experience of vulnerability.}

Insert table 2 here.

\section{Discussion}

This study draws from low-income unbanked consumers' accounts in order to illustrate the ways in which banks' justice elements are associated with those consumers' experiences of vulnerability. This research complies with recent calls for action in the service research 
community to enhance well-being of the poor in service settings (e.g., Fisk et al., 2016; Reynoso et al., 2015; Gebauer \& Reynoso, 2013). This study findings to complement the studies conducted on poor customers of financial services in TSR domain (e.g. SanchezBarrios et al., 2015; Martin \& Hill 2015) by addressing issue of their financial exclusion, which is considered to be one of the major issues with regards to their well-being in developing countries. It highlights the problems faced by low-income consumers in their financial inclusion and provides suggestions for serving them in a better manner both for their financial inclusion and to enhance their well-being. Drawing on justice theory and consumer vulnerability literature, the present study indicates how perceptions of banks' unfair service processes result in the experience of powerlessness and lack of control amongst the economically vulnerable consumers. Although the personal circumstances of low-income individuals hinder their financial inclusion to some extent, banks' prejudice against serving low-income consumers mainly cause them exclusion and powerlessness. The low-income consumers' standpoint highlights the fact that they are denied distributive, procedural and interactional justice by the banks.

The first theme describing banks' service was the avoidance of low-income consumers, which portrays both the distributive and interactional injustice of banks. Distributive justice as fairness has a built-in ethical element that indicates that it is the duty of organizations to distribute resources after a careful consideration of moral justification (Laczniak \& Murphy, 2008; Laczniak, 1999). Vulnerable consumers should be given unique consideration by the powerful party, i.e., the seller, when distributing resources (Rendtorff, 2009; Laczniak \& Murphy, 2008). Banks' reluctance to open branches in low-income neighbourhoods and rural areas creates geographical barriers to banking and exacerbates the 'structural vulnerability' of low-income consumers seeking to consume financial services. Structural circumstances are 
one of the several external factors that add to the broad conception of consumer vulnerability (Baker et al., 2005). Similarly, low-income consumers' lack of knowledge regarding banks reflects distributive unfairness. The poor face 'marketing exclusion', as banks avoid allocating resources for informing and targeting them due to their lack of profitability (Kempson \& Whyley, 1999), which leads the poor to experience 'information vulnerability'(Cartwright, 2011). Due to their marketing exclusion and information vulnerability, unbanked consumers manage their routine financial matters informally, which may result in detrimental feelings (Kempson \& Whyley,1999; Wang \& Tian, 2014; Cartwright, 2011).

Ethics in the services business is dependent on better treatment of vulnerable customers (Rendtorff, 2009). The vulnerable circumstances of low-income unbanked consumers warrant extra support from banks' service staff in completing those consumers' consumption goals (Brennan, 2006; Baker, 2006). However, bank staff has tried to avoid low-income participants through poor service, which indicates lack of an interactional justice component of banks.

The second theme in describing banks' service towards the unbanked consumers is discrimination, which signals procedural and interactional unfairness. Procedural justice principles are violated when customers in analogous situations are treated differently by a firm (Chung-Herrera, 2007). The low-income participants perceived that bank staff handles affluent customers with expedited procedures, which indicates the procedural unfairness of banks towards the poor. Likewise, low-income participants perceived discrimination when bank staff addressed them in a disrespectful way, illustrating interactional injustice towards the poor. Vulnerable consumers wish that sellers would address them with equality and 
respect (Baker, 2006). Discrimination in procedures and interactions lead the poor to experience vulnerability, as those low-income consumers perceive themselves as inferior to those who are given better treatment by bank staff.

Lastly, one of the procedural fairness principles is that organizations ensure that they consider the perspective of various groups who are affected by a decision (Leventhal et al., 1980; Colquitt et al., 2001). This research indicates that banks' account opening procedures impeded the financial inclusion of the poor. This represents a lack of procedural justice elements on the part of banks. Banks had similar procedures for opening accounts for both mainstream consumers and the low-income consumers despite these customer groups having very different resources and capabilities to fulfil the procedural requirements. This procedural unfairness was connected to the powerlessness and deprivation felt by the low-income participants.

Avoiding, discriminating and impeding financial inclusion reflect distributive, procedural and interactional unfairness. These forms of injustice can be regarded as unspoken strategies to discourage low-income customers in banks and thus achieve favourable financial outcomes for firms (Kotler \& Levy,1971). However, the ethics of these strategies can be questioned (Mayser \& von Wangenheim, 2013), in particular, when consumers are left without comparable substitutes (Kotler \& Levy, 1971). The financial service organizations exclude the poor from basic financial services without considering the impact of their actions on the excluded consumers. Financial exclusion imposes considerable costs on the unbanked population although the poor are interested in their financial inclusion (Solo, 2008)to escape their vulnerable circumstances (Wang \& Tian, 2014). This necessitates a change in the attitude of different financial services entities (Anderson et al., 2013) towards serving the 
poor. Financial service entities such as the regulator, banks' top management and frontline employees can collectively ensure fairness for low-income consumers through policies, procedures and actions.

\subsection{Public policy implications}

We propose a number of policy implications for delivering impartial banking services to lowincome consumers, which could enhance their well-being and alleviate their vulnerability. Because this study was conducted in Pakistan, the policy implications are directly applicable there but could also be relevant to other developing countries with massive unbanked population. The lack of banks' fairness towards the poor is a major cause of their exclusion from mainstream financial services and onward experience of vulnerability. Therefore, banks regulators should introduce viable mechanisms to protect and serve low-income consumers in developing countries.

The low-income unbanked consumers' perception of being avoided by financial services providers can be overcome by enhancing access to bank branches in remote areas and by educating the poor about financial services. Participants with a rural background (i.e., migrant workers) typically encountered 'structural vulnerability'(Baker et al.,2005) in their attempt to utilize basic banking services while living in their villages. Their experience of structural vulnerability can be alleviated by opening more branches in rural areas. Presently, Pakistani commercial banks are bound to open at least $20 \%$ of their new branches in rural and underserved areas (The banker, 2015),but $61 \%$ of the Pakistani population resides in villages (World databank, 2015). Likewise, many developing countries in Asia and Africa have more than $60 \%$ rural population (World databank, 2015). The rural population encounter structural 
vulnerability in accessing basic financial services in other developing countries too. Therefore, to enforce distributive justice for the poor, the regulators in respective countries could consider making it mandatory for commercial banks to open at least $50 \%$ of new bank branches in unserved or underserved rural areas. Moreover, due to widespread illiteracy in developing countries, the poor generally lack adequate knowledge about the benefits of opening a bank account (Chopra, et al., 2017). Thus, the banks regulator and NGOs promoting financial inclusion could launch educational programmes to enhance basic financial knowledge amongst low-income consumers in various developing countries in order to improve their financial inclusion.

This study illustrated instances in which bank staff followed discriminatory procedural treatments, showed disrespect and provided poor service to their low-income customers, which is certainly not part of the official code of conduct for banks' business. This might not be the policy of banks, but it could be followed by some frontline employees and ignored by the managers when observed. To enhance procedural and interactional fairness for the poor, banks could educate their staff about their business code of conduct and train them to effectively address the low-income consumers. Due to their personal circumstances, these consumers warrant extra support in completing their transactions.

Finally, low-income consumers' perceived impediments in opening a basic bank account has recently been addressed by the regulator to some extent, but room for improvement still exists. When the data collection was complete, there were mandatory documentary and initial deposit requirements for opening a bank account. However, on the recent instruction of the regulator, an Aasan account has been launched specifically for low-income consumers. This account can be opened by completing a form and by providing a copy of a national identity 
card. This is a very encouraging step towards the financial inclusion of the poor, as it eliminates some of the procedural issues faced by the poor. However, this study also illustrates that low-income consumers in general lack knowledge about the benefits of using a bank account, and they usually lack literacy skills to do so. Therefore, the Aasan bank account should be promoted by banks through viable communication channels that can deliver verbal information to the target market. Apart from the national language, Aasan account commercials should be aired in different provincial languages because some rural populations can only speak or understand their mother tongue. Researchers in some other developing countries have also reported that initial deposit and documentation requirements discourage the poor consumers financial inclusion (e.g. Solo, 2008). Therefore, banks regulators and financial service providers should assess the basic account opening requirements and simplify the process, where applicable.

\subsection{Study limitations and future research directions}

First, the sample for this study was drawn from low-income consumers. This study did not incorporate the views of unbanked consumers from other social classes with respect to the banks' fairness. Future studies could investigate the perceived fairness of banks amongst consumers from other income stratums. Second, this study only takes the perspective of the unbanked consumers; it does not incorporate the difficulties faced by the bank staff in dealing with the low-income consumers. Therefore, future studies could explore challenges and complications encountered by banks' frontline staff in serving low-income consumers. Third, the role of service employees and managers is vital in serving vulnerable customers in a fair manner. Future studies could explore how bank staff and managers perceive fairness for poor customers and how they perceive their role in assisting the poor customers in mitigating their 
potential vulnerability with regards to financial services. Fourth, this research advocates lowincome consumers' financial inclusion and well-being by investigating their perspective. However, those who directly serve vulnerable customers could also encounter vulnerability (i.e., due to banks' poor working conditions specifically in developing countries' milieu). Another study in the realm of TSR could examine how banks' working conditions assist or impede frontline employees in serving vulnerable customers fairly. The research may comprehend the potential workplace problems faced by banks' service employees and propose implications for their well-being. Lastly, mainstream consumers may encounter difficulties in different service settings, which may trigger a perception of unfairness and experience of vulnerability. For instance, many ordinary consumers encounter problems in understanding financial product information (Cartwright, 2011). However, their perceptions and experience of vulnerability might differ from vulnerable consumers. Thus, there is a potential to empirically explore patterns of service providers unfairness and consumers experience of vulnerability with regard to other consumer groups and in other service sectors.

\section{References}

Anderson, L., Ostrom, A.L., Corus, C., Fisk, R.P., Gallan, A.S., Giraldo, M., Mende, M., Mulder, M., Rayburn, S.W., Rosenbaum, M.S. and Shirahada, K., (2013), Transformative service research: an agenda for the future. Journal of Business Research, 66(8), 1203-1210. doi: https://doi.org/10.1016/j.jbusres.2012.08.013

Baker, S. M. (2006). Consumer normalcy: Understanding the value of shopping through narratives of consumers with visual impairments. Journal of retailing, 82(1), 37-50.doi: https://doi.org/10.1016/j.jretai.2005.11.003

Baker, S. M., Gentry, J. W., and Rittenburg, T. L. (2005).Building understanding of the domain of consumer vulnerability. Journal of Macromarketing, 25(2), 128-139.doi: https://doi.org/10.1177/0276146705280622

Baker, S. M., Hunt, D. M., and Rittenburg, T. L. (2007). Consumer vulnerability as a shared experience: Tornado recovery process in Wright, Wyoming. Journal of Public Policy \& Marketing, 26(1), 6-19.doi.https://doi.org/10.1509/jppm.26.1.6 
Bird, C. M. (2005). How I stopped dreading and learned to love transcription. Qualitative inquiry, 11(2), 226-248.doi: https://doi.org/10.1177/1077800404273413

Blodgett, J., Hill, D., and Tax, S. (1997), The effects of distributive, procedural and interactional justice on post complaint behavior, Journal of Retailing, 73 (2),185-210. doi: https://doi.org/10.1016/S0022-4359(97)90003-8

Braun, V., and Clarke, V. (2006).Using thematic analysis in psychology.Qualitative research in psychology, 3(2), 77-101.doi: http://dx.doi.org/10.1191/1478088706qp063oa

Brennan, C. (2006). Empowering vulnerable consumers in the KBE: Taking forward policy, knowledge and a new alliance for consumer education. Paper presented at Institute for advanced studies workshop: Consumers and the knowledge based economy. Lancaster: Lancaster University.

Canhoto, A. I., and Dibb, S. (2016). Unpacking the interplay between organisational factors and the economic environment in the creation of consumer vulnerability. Journal of Marketing Management, 32(3-4), $335-$ 356.doi.http://dx.doi.org/10.1080/0267257X.2015.1123759

Cartwright, P. (2011). The Vulnerable Consumer of Financial Services: Law, Policy \& Regulation, Financial Services Research Forum. University of Nottingham, Nottingham, UK.

Chéron, E. J., Boidin, H., and Daghfous, N. (1999). Basic financial services needs of lowincome individuals: a comparative study in Canada. International Journal of Bank Marketing, 17(2), 49-64. doi: http://dx.doi.org/10.1108/02652329910258826

Chopra, Y., Prabhala, N., and Tantri, P. L. (2017). Bank Accounts For The Unbanked: Evidence from a Big Bang Experiment.

Chung-Herrera, B. G. (2007). Customers' psychological needs in different service industries. Journal of Services Marketing, 21(4), 263-269. doi: http://dx.doi.org/10.1108/08876040710758568

Colquitt, J., Conlon, D., Wesson, M., Porter, C. and Ng, Y. (2001). Justice at the millennium: a meta-analytic review of 25 years of organizational justice research. Journal of Applied Psychology, 86(3), 425-445. doi: http://dx.doi.org/10.1037/0021-9010.86.3.425

Corus, C., andSaatcioglu, B. (2015).An intersectionality framework for transformative services research. The Service Industries Journal, 35(7-8), 415-429 doi: http://dx.doi.org/10.1080/02642069.2015.1015522

Demirguc-Kunt, A., Klapper,L., Singer, D. and van Oudheusden, P.(2015). The Global Findex Database 2014: Measuring Financial Inclusion around the World. Policy Research Working Paper 7255, World Bank, Washington, DC.

Deutsch, M. (1975). Equity, Equality, and Need: What Determines Which Value Will Be Used as the Basis of Distributive Justice. Journal of Social Issues, 31 (3),137-149. doi: 10.1111/j.1540-4560.1975.tb01000.x 
Elliott, R. and Jankel-Elliott, N. (2003).Using ethnography in strategic consumer research. Qualitative Market Research An International Journal 6(4), 215-223. doi: 10.1108/13522750310495300

Fisk, R.P.P. (2009). A customer liberation manifesto. Service Science, 1 (3), 135141.doi:https://doi.org/10.1287/serv.1.3.135

Fisk, R.P.P., Anderson, L., Bowen, D.E., Gruber, T., Ostrom, A., Patrício, L., Reynoso, J. and Sebastiani, R. (2016). Billions of impoverished people deserve to be better served: A call to action for the service research community. Journal of Service Management, 27(1), 43-55. doi: http://dx.doi.org/10.1108/JOSM-04-2015-0125

Gebauer, H., and Reynoso, J. (2013).An agenda for service research at the base of the pyramid. Journal of Service Management, 24(5), 482-502. doi: http://dx.doi.org/10.1108/JOSM-04-2013-0090

Gentry, J. W., Kennedy, P. F., Paul, K., and Hill, R. P. (1995). The vulnerability of those grieving the death of a loved one: Implications for public policy. Journal of Public Policy \& Marketing, 128-142.http://www.jstor.org/stable/30000385

Gundlach, G. T., and Murphy, P. E. (1993).Ethical and legal foundations of relational marketing exchanges. The Journal of Marketing, 57 (4), 35-46.

Hill, R. P., and Stephens, D. L. (1997). Impoverished Consumers and Consumer Behavior: The Case of AFDC Mothers, Journal of Macromarketing, 17, (2), 32-48. doi:https://doi.org/10.1177/027614679701700204

Kempson, E., and Whyley, C.(1999). Kept out or opted out? Understanding and combating financial exclusion. Bristol: Policy Press.

Kennedy, A. M., and Laczniak, G. R. (2016). Conceptualisations of the consumer in marketing thought. European Journal of Marketing, 50(1/2), 166-188. doi: http://dx.doi.org/10.1108/EJM-10-2014-0608

Klein, T. A. (2008). Assessing distributive justice in marketing: a benefit-cost approach. Journal of Macromarketing, 28 (1), 33-43. doi: https://doi.org/10.1177/0276146707311243

Kochhar, R. (2015). A Global Middle Class Is More Promise than Reality: From 2001 to 2011, Nearly 700 Million Step Out of Poverty, but Most Only Barely. Pew Research Center, Washington, D.C.

Koku, P. S. (2009). Doing well by doing good-marketing strategy to help the poor: The case of commercial banks in Ghana. Journal of Financial Services Marketing, 14(2), 135-151.doi: $10.1057 /$ fsm.2009.13

Koku, P.S. (2015), Financial exclusion of the poor: a literature review, International Journal of Bank Marketing, 33 (5), 654 - 668. doi: http://dx.doi.org/10.1108/IJBM-09-2014-0134

Kotler, P., and Levy, S. J. (1971). Demarketing, yes, demarketing. Harvard Business Review, 49(6), 74-80. 
Laczniak, G. R. (1999). Distributive justice, Catholic social teaching and the moral responsibility of marketers. Journal of Public Policy \& Marketing, 18 (1),125-29.

Laczniak, G. R., and Murphy, P. E. (2008). Distributive justice: Pressing questions, emerging directions, and the promise of Rawlsian analysis. Journal of Macromarketing, 28 (1),5-11. doi: https://doi.org/10.1177/0276146707312214

Laureti, C. (2017). Why do Poor People Co-hold Debt and Liquid Savings? The Journal of Development Studies, 1-22. DOI: 10.1080/00220388.2017.1299137

Leventhal, J., J. Karuza, and W.R. Fry. (1980). Beyond Fairness: A Theory of Allocation Preferences. Pp. 167-218 in G. Mikula(ed.), Justice and Social interaction. New York: Springer-Verlag.

Martin, K. D., and Hill, R. P. (2015). Saving and well-being at the base of the pyramid: Implications for transformative financial services delivery. Journal of Service Research, 18(3), 405-421.doi:10.1177/1094670514563496

Mayser, S., and von Wangenheim, F. (2013). Perceived Fairness of Differential Customer Treatment Consumers' Understanding of Distributive Justice Really Matters. Journal of Service Research, 16(1), 99-113. doi: https://doi.org/10.1177/1094670512464274

Mick, D. G. (2006). Presidential address: Meaning and mattering through transformative consumer research. In C. Pechmann, \& L. L. Price (Eds.), AdvConsum Res, Vol. 33. (pp. 14)Duluth, MN: Association for Consumer Research.

Morgan, F. W., Schuler, D. K., and Stoltman, J. J. (1995).A framework for examining the legal status of vulnerable consumers. Journal of Public Policy \& Marketing, 14(2) 267-277. http://www.jstor.org/stable/30000134

Myers, M. D. (2013). Qualitative research in business and management2nd edition. London, Sage.

Namkung, Y. and Jang, S. (2009). The effects of interactional fairness on satisfaction and behavioral intentions: Mature versus non-mature customers.International Journal of Hospitality Management, 28 (3), 397-405.doi:https://doi.org/10.1016/j.ijhm.2008.11.001

Nance, W., and White, D. (2009). Service performance and procedural justice: the mediating roles of family life cycle and culture. Journal of Services Marketing, 23(3), 195-207.doi: $10.1108 / 08876040910955206$

Pera, R., and Viglia, G. (2015).Turning ideas into products: subjective well-being in cocreation. The Service Industries Journal,35(7-8), 388-402. doi: http://dx.doi.org/10.1080/02642069.2015.1015521

Rayburn, S. W. (2015). Consumers' captive service experiences: it's YOU and ME. The Service Industries Journal, 35(15-16), 825.doi:http://dx.doi.org/10.1080/02642069.2015.1090982 
Rendtorff, J. D. (2009). Basic ethical principles applied to service industries. The Service Industries Journal, 29(1), 9-19.doi: http://dx.doi.org/10.1080/02642060802116404

Reynoso, J., Valdés, A., \& Cabrera, K. (2015).Breaking new ground: base-of-pyramid service research. The Service Industries Journal, 35(13), 695709.doi:http://dx.doi.org/10.1080/02642069.2015.1079818

Ringold, D. J. (1995). Social criticisms of target marketing: Process or product. American Behavioral Scientist 38 (4), 578-592. doi:https://doi.org/10.1177/0002764295038004008

Saatcioglu, B., and Corus, C. (2016).Exploring spatial vulnerability: inequality and agency formulations in social space. Journal of Marketing Management, 32(3-4), 230251.http://dx.doi.org/10.1080/0267257X.2015.1103775

Sanchez-Barrios, J, L., Giraldo, M., Khalik, M., \& Manjarres, R. (2015). Services for the underserved: unintended well-being. The Service Industries Journal, 35(15-16), 883897.doi:10.1080/02642069.2015.1090983

Seiders, K., and Berry, L. L. (1998). Service fairness: What it is and why it matters. The Academy of Management Executive, 12(2), 8-20.doi: 10.5465/AME.1998.650513

Smith, N. C., and Cooper-Martin, E. (1997). Ethics and target marketing: The role of product harm and consumer vulnerability. The Journal of Marketing, 61(3) p.1-20.doi: $10.2307 / 1251786$

Solo, T. M. (2008).Financial exclusion in Latin America-or the social costs of not banking the urban poor. Environment and Urbanization, 20(1), 47-66. doi: https://doi.org/10.1177/0956247808089148

Speak, S. (2000). Back to the well: the hidden costs of service exclusion for the network poor. Journal of Consumer Studies \& Home Economics, 24 (1), 49-59. doi:10.1046/j.13652737.2000.00124.x

Tax, S., Brown, S., and Chandrashekaran, M. (1998). Customer Evaluations of Service Complaint Experiences: Implications for Relationship Marketing. Journal of Marketing, 62 (2), 60-76. doi:10.2307/1252161

The banker.(2015). Banks required to open 20\% new branches in rural areas: Dar, The banker Pakistan, Financial Tribune of Pakistan. Retrieved from: http://www.thebanker.com.pk/financial_sector/banks-required-to-open-20-new-branches-inrural-areas-dar

Wang J, J., and Tian, Q. (2014).Consumer Vulnerability and Marketplace Exclusion: A Case of Rural Migrants and Financial Services in China. Journal of Macromarketing, 3, 4(1) 45 56. doi: https://doi.org/10.1177/0276146713508137

World databank.(2015). The World Bank:Rural population (\% of total population)

Retrieved from:http://data.worldbank.org/indicator/SP.RUR.TOTL.ZS 
Worthington, S., and Devlin, J. (2013). Fairness and financial services in Australia and the United Kingdom. International Journal of Bank Marketing, 31 (4), 289-304.doi: http://dx.doi.org/10.1108/IJBM-09-2012-0094

Table 1: Participant profiles

\begin{tabular}{|c|c|c|c|c|c|c|c|}
\hline S\# & Alias & Sex & Age & Occupation & Education & Income & Residence \\
\hline 1 & Jani & $\mathrm{M}$ & 43 & Water Bore Worker & High School & $15000-20000$ & Local \\
\hline 2 & Mani & $\mathrm{M}$ & 27 & Café Worker & High School & 12,000 & MW \\
\hline 3 & Papu & $\mathrm{M}$ & 26 & Tailor & School Leaver & $17000-18000$ & MW \\
\hline 4 & Khan & $\mathrm{M}$ & 44 & Taxi Driver & Illiterate & $15000-16000$ & Local \\
\hline 5 & Bano & FM & 36 & Housemaid & Illiterate & 15000 & MW \\
\hline 6 & Raja & $\mathrm{M}$ & 41 & Vegetable Seller & School Leaver & $15000-17000$ & Local \\
\hline 7 & Izza & FM & 55 & Housewife & School Leaver & 20,000 & Local \\
\hline 8 & Rani & FM & 25 & Housemaid & Illiterate & 8000 & MW \\
\hline 9 & Pola & $\mathrm{M}$ & 29 & Grocery Shopkeeper & Undergraduate & $15000-16000$ & MW \\
\hline 10 & Nomi & $\mathrm{M}$ & 21 & Cashier in Café & Completed School & 11000 & MW \\
\hline 11 & Nori & FM & 40 & Cleaner in School & Illiterate & $7000-8000$ & MW \\
\hline 12 & Babu & $\mathrm{M}$ & 42 & Whitewasher & Completed College & $12000-15000$ & Local \\
\hline 13 & Jelo & FM & 40 & Pvt School Teacher & Completed College & 7000 & Local \\
\hline 14 & Shan & $\mathrm{M}$ & 26 & Salesman in a Shop & High School & 10000 & MW \\
\hline 15 & Niaz & $\mathrm{M}$ & 26 & Tailor & Illiterate & $15000-18000$ & MW \\
\hline 16 & Bibi & FM & 45 & Housemaid & Illiterate & 8500 & MW \\
\hline 17 & Babli & $\mathrm{FM}$ & 46 & Tailoring from Home & Illiterate & $10000-12000$ & MW \\
\hline 18 & Sami & $\mathrm{M}$ & 22 & Grocery Shopkeeper & School Leaver & $15000-20000$ & MW \\
\hline 19 & Bari & $\mathrm{M}$ & 34 & Barber & Illiterate & $10000-12000$ & MW \\
\hline 20 & Rema & FM & 23 & Housemaid & Illiterate & $7000-8000$ & MW \\
\hline 21 & Mana & $\bar{M}$ & 24 & Cleaner in a Firm & School Leaver & 7500 & MW \\
\hline 22 & Malik & $\mathrm{M}$ & 47 & Labour Supervisor & School Leaver & $15000-20000$ & MW \\
\hline 23 & Nelo & FM & 25 & Housemaid & Illiterate & 10000 & MW \\
\hline 24 & Noor & $\mathrm{M}$ & 32 & Tailor & Illiterate & $10000-12000$ & MW \\
\hline 25 & Rifi & FM & 50 & Housemaid & School Leaver & 10000 & MW \\
\hline 26 & Zain & $\mathrm{M}$ & 30 & Tailor & School Leaver & $15000-20000$ & MW \\
\hline 27 & Sher & $\mathrm{M}$ & 64 & Dry Cleaner & School Leaver & $10000-15000$ & Local \\
\hline 28 & Kaka & $\mathrm{M}$ & 26 & Welder & School Leaver & 13000 & Local \\
\hline 29 & Billa & $\mathrm{M}$ & 40 & Taxi Driver & Completed School & $20000-25000$ & Local \\
\hline 30 & Phol & $\mathrm{M}$ & 46 & Taxi Driver & School Leaver & $22000-23000$ & Local \\
\hline 31 & Sema & $\mathrm{FM}$ & 25 & Tailoring from Home & Illiterate & $15000-16000$ & MW \\
\hline 32 & Teto & $\mathrm{M}$ & 26 & Grocery Shopkeeper & School Leaver & $18000-20000$ & Local \\
\hline 33 & Chand & $\mathrm{M}$ & 40 & Tailor & School Leaver & $25000-26000$ & MW \\
\hline 34 & Gama & $\mathrm{M}$ & 35 & Hawker/Sweets Seller & Illiterate & 10000 & MW \\
\hline 35 & Laila & FM & 40 & Housemaid & Illiterate & $15000-16000$ & MW \\
\hline 36 & Sana & FM & 35 & Pvt. School Attendant & Illiterate & 10000 & MW \\
\hline 37 & Gul & $\mathrm{M}$ & 25 & Salesman in a Shop & School Leaver & 8000 & Local \\
\hline
\end{tabular}


Table 2: Perceptions of fairness dimensions

\begin{tabular}{|c|c|c|}
\hline Themes & Justice elements of banks & $\begin{array}{l}\text { Examples of consumer experiences of } \\
\text { vulnerability }\end{array}$ \\
\hline $\begin{array}{l}\text { 1. Avoiding } \\
\text { (a) Geographical barriers } \\
\text { (b) Lack of information } \\
\text { about banks } \\
\text { (c) Poor service }\end{array}$ & $\begin{array}{l}\text { Distributive justice element } \\
\text { Distributive justice element } \\
\text { Interactional justice element }\end{array}$ & $\begin{array}{l}\text { Higher transportation and time costs. } \\
\text { Perceive little need to open bank account. } \\
\text { Time wastage and decrease in daily income. }\end{array}$ \\
\hline $\begin{array}{l}\text { 2. Discriminating } \\
\text { (a) Discriminatory } \\
\text { procedural treatment } \\
\text { (b) Disrespectful } \\
\text { behaviour of bank staff }\end{array}$ & $\begin{array}{l}\text { Procedural justice element } \\
\text { Interactional justice element }\end{array}$ & $\begin{array}{l}\text { Feelings of powerlessness and inferiority. } \\
\text { Perceived themselves less than others and } \\
\text { insulted. }\end{array}$ \\
\hline $\begin{array}{l}\text { 3. Impeding } \\
\text { (a) Documentation } \\
\text { requirement } \\
\text { (b)Initial deposit } \\
\text { requirement }\end{array}$ & $\begin{array}{l}\text { Procedural justice element } \\
\text { Procedural justice element }\end{array}$ & $\begin{array}{l}\text { Feelings of helplessness, lack of control and } \\
\text { powerlessness. }\end{array}$ \\
\hline
\end{tabular}

